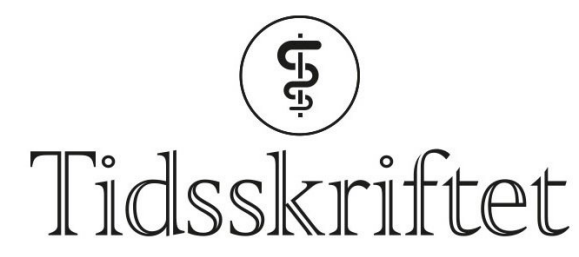

DEN NORSKE LEGEFORENING

\title{
Artikkelsamling om ei vid helseforståing
}

ANMELDELSER

\section{ASLAK BRÅTVEIT}

Sjukeheimslege, spesialist i allmennmedisin Finnøy sjukeheim

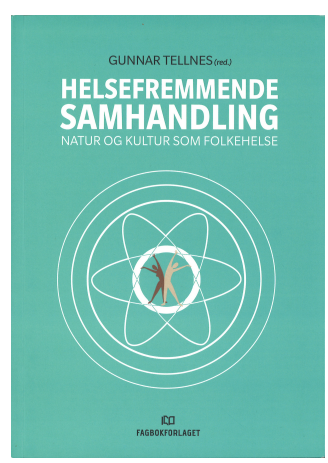

Gunnar Tellnes

Helsefremmende samhandling

Natur og kultur som folkehelse. 210 s, ill. Bergen: Fagbokforlaget, 2017. Pris NOK 299

ISBN 978-82-450-1696-3

Gunnar Tellnes er professor i samfunnsmedisin i Oslo. Han har invitert 18 fagfolk til å skrive kortfatta om forskjellige tema som kvar for seg kan påverke helse. Sidan temaet er helsefremjande samhandling, går han ikkje inn i klassisk medisin, der biologiske og psykiske tilstandar hjå den einskilde skal diagnostiserast og behandlast. Dyktiggjering og helseforbetring skjer best i grupper, i samhandling, påstår han.

Artiklane har røter i akademia, men ber også i seg praktisk erfaring. Tellnes har både redigert og gitt bidrag til boka, i innleiing og avslutting presenterer han NaKuHel-senteret $\mathrm{i}$ Asker, ein møtestad og eit aktivitetssenter for einskildpersonar og grupper.

Boka er ein introduksjon til ei utvida og mangefasettert forståing av helse og vegar til helseforbetring. Mangfaldet og dei mange påstandane inviterer lite til debatt. Målgrupper er studentar og aktørar innan folkehelse, samfunnsmedisin og førebyggjande helsearbeid. Tellnes listar også opp folkehelsekoordinatorar, legar, sjukepleiarar, psykologar og lærarar, tilsette i ideelle organisasjonar, Nav, sosialomsorg, offentlege etatar og næringsliv som målgrupper.

Kapitla omhandlar emne som natur, kultur, evolusjon, tilhøyring, samfunnshelse, leiing, 
helsestasjon, friluftsliv, turgåing, musikk, dans, kunst, arkitektur, berekraft, mentale lidingar, demens, migrasjon, trygge lokalsamfunn og «grøn omsorg».

Tekstane er kortfatta og overkomelege. Dei vert fylgde av rikhaldige kjeldetilvisingar. Sju bilete av norsk natur i svart-kvitt understrekar natur og turaspektet. Ein geometrisk figur freistar illustrere samanhengar og mangfaldet som eit resymé av boka.

Forfattarane har ulik tilnærming, frå påstandar til akademi og forsking eller situasjonsbeskriving. Det vernar mot keisemd. Dei lange referanselistene kunne vore korta ned (15-40 for kvart kapittel).

Fleire sider av samfunns- og kulturliv er omtala som verdifulle for meistring og helse. Boka vert difor eit politisk innspel og skulle ha interesse for politikarar.

Publisert: 5. mars 2018. Tidsskr Nor Legeforen. DOI: 10.4045/tidsskr.17.1046

(C) Tidsskrift for Den norske legeforening 2020. Lastet ned fra tidsskriftet.no 